The Catholic University of America, Columbus School of Law

CUA Law Scholarship Repository

\title{
The Supreme Court in American Popular Culture
}

Maxwell Bloomfield

The Catholic University of America, Columbus School of Law

Follow this and additional works at: https://scholarship.law.edu/scholar

Part of the Judges Commons

\section{Recommended Citation}

Maxwell Bloomfield, The Supreme Court in American Popular Culture, 4 J. AM. CULTURE 1 (1981).

This Article is brought to you for free and open access by the Faculty Scholarship at CUA Law Scholarship Repository. It has been accepted for inclusion in Scholarly Articles and Other Contributions by an authorized administrator of CUA Law Scholarship Repository. For more information, please contact edinger@law.edu. 


\section{The Supreme Court in American Popular Culture}

\section{Maxwell Bloomfield}

Until quite recently the judiciary-and the federal judiciary in particular-has been largely neglected by American novelists and playwrights. Literary historians such as Joseph Blotner and Gordon Milne, who have studied the American political novel in the nineteenth and twentieth centuries, have found an abundance of works dealing with legislative or executive skulduggery, but only a handful of titles that examine issues of judicial power.' Such relative disinterest in our noblesse de robe seems easily-explainable. Judges have always been less visible to the public than, say, Congressmen or Governors, and the business of judging does not lend itself readily to dramatization.

I should qualify that last statement a bit. Writers of mystery and detective fiction-a genre of little interest to academic critics in the pasthave presented trial judges to their readers on innumerable occasions, and the courtroom drama has been popular with theater audiences since the days of the early Republic." The stylized procedure of a criminal trial is rich in dramatic possibilities, and one need not know a great deal about the law to write a first-rate thriller. Indeed, the authors of such works tend to avoid abstraction wherever possible, relying instead upon factual detail and characterization to attract readers. The typical mystery or crime novel describes a battle of wits between opposing counsel, while the judge remains a shadowy, and relatively inarticulate, presence in the background.

But creative writers must deal with substantive legal doctrines if they shift their scene from the trial to the appellate court. At the appellate level principles overshadow personalities, and the dramatic options offered by the adversary system are severely circumscribed. Hence there are few fictional treatments of appellate proceedings, and the historian who wishes to assess the popular impact of a tribunal such as the United States Supreme Court must rely upon scattered bits of evidence gathered from a wide variety of sources. I use the term "popular culture" very loosely, then, to denote any Court-related materials that were designed for a general audience, regardless of their actual distribution or influence. An examination of such materials may, I hope, shed some further light on the interaction between social values and legal change at various periods in our national history. At the very least it will afford a closer look at what certain articulate Americans thought the Court was doing, or should do, to fulfill its responsibilities to the public.

The initial record is rather meager. During the first century of its existence the Court made only a limited impression upon the popular 
consciousness. To the average American of the antebellum years Washington seemed a distant-almost a foreign-capital, whose power seldom intruded in any dramatic fashion upon one's daily life. Republican government, as practiced in a decentralized and sparsely populated country, implied strong local and regional loyalties, as well as a permissive legal environment that encouraged private entrepreneurial activity and capital accumulation. Within the federal system the Supreme Court served as an essential balancing force in determining the proper limits of state and national power. Yet the judicial role, as defined authoritatively by Chief Justice John Marshall, was not calculated to stir the imagination. "Judicial power, as contradistinguished from the power of the laws, has no existence," Marshall wrote in Osborne v. Bank of the United States (1924). "Courts are the mere instruments of the law, and can will nothing. When they are said to exercise a discretion it is a mere legal discretion, a discretion to be exercised in discerning the course prescribed by law....": Nineteenthcentury Americans tended, on the whole, to accept this formulation, which rather discouraged the literary muse.

Thus, the earliest glimpses of the Court in American fiction occur as set pieces in satirical travelogues. Generally one character is showing another around the Capitol, and they pay a brief visit to the courtroom. The furniture is described in greater detail than the Justices, who are pictured as emblems of republican virtue: aged, wise, and serene beings who are capable of listening to boring arguments for days without murmur. Such terms as "reverned," "venerable," "upright" and "impartial" recur from book to book. The prototype of this kind of writing was Charles Jared Ingersoll's Inchiquin, The Jesuit's Letters, During a Late Residence in the United States of America (1810), a parody of the hostile travel accounts then being written by foreign visitors.

More representative, however, is George Watterston's The L.... Family at Washington (1822). Watterston had a keen eye for humorous detail, but his tone sobered perceptibly as he escorted his readers into the Supreme Court chamber:

...a semicircular apartment, of the same form, and nearly of the same dimensions, as the Senate Chamber, which is immediately above it. It appeared to me rather heavy and dark, for the purposes of justice, but the luminaries of the law, I supposed, required no additional aid from the sun, to enable them to apply principles, and decide on controversies... The Court-room was very handsomely furnished with sofas, lounges, armed chairs \&c. and the judges were arrayed in their gowns, or robes, of black silk. This, said I, is the supreme judicial tribunal of our great republic, as the Europeans have very justly called it. It is, as it ought to be, an independent branch of the Government, and presides over controversies of the first importance, and the deepest interest to the country, with, I trust, an impartial and unbiased judgment."

Watterston then described the physical appearance of several Justices and lawyers, and noted that the Court had recently been criticized for giving biased decisions that favored national over state interests. Such charges were groundless, he argued, since the Justices could hope for no higher reward from the federal government than they already possessed. 
"[I]f their feelings should be permitted to operate at all," he concluded, "the sacred regard they must feel for their character as judges, their judgment as lawyers, and their reputation as men, would check the influence of those feelings, and most certainly prevent them from sacrificing the rights of the State sovereignties composing our Union, at the shrine of the general Government."

Here we have an early statement of what might be termed the "mystique of the robe." Note the religious connotations of such words as "sacred" and "shrine." From Watterston's day to the present, writers have endowed the judicial role with almost magical properties of character building and intellectual enlightenment. Donning the black robe, especially at the Supreme Court level, is, one gathers, a bit like entering the priesthood or at least the Salvation Army. Chief Justice Harry Griffin, a character in Jay Broad's play A Conflict of Interest (1972), puts the matter quite nicely. "People assume" says Griffin, "that when a man becomes a member of the Court, he is beatified and from that day hence, like a saint, he does not even have to go to the bathroom. Of course, statistically we can prove we do. Last year the members of the Court used three hundred and eighty dollars worth of toilet paper."';

A few nineteenth-century biographers carried the hagiology of the high bench to its logical conclusion by insisting that their subjects had always behaved like wise and disinterested judges. Henry Flanders, in The Lives and Times of the Chief Justices of the Supreme Court of the United States (1858), presented John Marshall to his readers as a model of professional decorum and impartiality throughout his public career, overlooking Marshall's record of flagrant political partisanship. Another pioneer Court historian, George Van Santvoord, after examining Roger Taney's role in the Bank War of the 1830s, concluded that Taney had acted with "fearless independence" in obeying President Andrew Jackson's order to remove federal deposits from the Bank of the United States. ${ }^{7}$ In a similar vein five popular textbooks used in elementary schools before the Civil War praised Marshall's statesmanlike conduct on the bench and credited him with an "almost supernatural faculty for getting to the heart of the discussion" in his opinions."

The Court also had its critics, of course. Decisions that struck down state laws or otherwise enlarged federal power became the subject of heated public debate at times. Antebellum newspapers commonly published important Court opinions, together with editorial comment and responses from readers. Through such journals defenders of state sovereignty denounced the Court for its centralizing tendencies and sometimes attacked the Justices personally for playing politics from the bench. Charges of bias multiplied as the Court was drawn into the slavery controversy, and judicial credibility sank to an all-time low with the announcement of the Dred Scott decision in 1857. That decision, which inspired a great body of polemical literature, found its way as well into one of the earliest black novels to appear in the United States.

Martin R. Delany's Blake; or, The Huts of America, a story of slave insurrection, featured a bigoted Northern judge who boasts of having 
decided the first test case under the new fugitive slave law in favor of the South. Quoting almost verbatim from Taney's opinion in the Dred Scott case, Judge Ballard tells a group of Southern planters: "It was a just decision of the Supreme Court-though I was in advance of it by [my] action-that persons of African descent have no rights that white men are bound to respect!"' Elsewhere Delany contrasts Taney ("the puppet figure... of the American Supreme Court") with Chief Justice Mansfield of England, a jurist of "colossal stature," who had ruled in Sommersett's Case (1772) that any slave brought to England was automatically entitled to his freedom."1"

Although nineteenth-century criticism of the Court for its alleged ideological bias or for improper lawmaking has a distinctly modern ring, one should not overemphasize its significance. Such criticism was limited and sporadic; it represented an extreme reaction to a handful of particularly controversial decisions. Most Americans of the time did not think of the Court in political terms, or consider the judicial function as involving any kind of creative policy-making. The Marshallian view of the judge's role, with its negative and mechanistic overtones, continued to guide popular thinking about the Court until well into the twentieth century. Hence one finds, as in the antebellum years, only scattered and marginal references to the high bench in the imaginative literature of the Gilded Age.

The best political novels of that era, such as Henry Adams' Democracy (1880) and John William De Forest's Honest John Vane (1875) and Playing the Mischief (1875), ignored the Court in their otherwise searching analyses of the Washington scene. Lesser writers sometimes introduced judicial characters into their narratives, but only for purposes of local color. Albert Gallatin Riddle devoted an entire chapter of his novel Alice Brand (1875) to a reception given by Chief Justice Salmon P. Chase. Apart from suggesting the prominence enjoyed by Court members in Washington's social circles, the account added nothing to the barebones treatment of the Justices provided by antebellum travelogues. Chase is described, with conventional reverence, as "genial, yet stately," and the only breakthrough of sorts comes from Riddle's choice of religious imagery: He compares the Chief Justice to a "sitting idol of Buddha," who dwarfs his brethren on the bench. Neither in this novel nor in any other nineteenth-century fiction does the Court ever decide a case. Its inner workings remain a mystery to laymen, even to those inveterate buyers of fictional guidebooks, whose popularityas evidenced by such later titles as $A$ Washington Winter (1883) and Around the Capital With Uncle Hank (1902)-appears equally inscrutable. ${ }^{11}$

By the 1890s a reassessment of the pietistic mythology associated with the Court was long overdue. The aristocratic agrarian republic of Washington and Jefferson, which had nurtured the earliest public images of the Court, had long ceased to exist. In its place had arisen a modern industrial nation, whose bloody class conflicts threatened at times to overwhelm a political system still wedded to laissez-faire values. Turn-ofthe-century reformers, fearing a successful Socialist revolution, attempted to make existing legal and political structures more responsive to the needs of an urban-industrial society. In the process they established the 
intellectual-and, to a lesser extent, the institutional-foundations of the welfare state.

The initial response of the Supreme Court to such reform initiatives was negative. During the first five months of 1895 the Court refused to apply the Sherman Act against the notorious Sugar Trust; invalidated a popular, and well publicized, federal income tax law; and approved the issuance by federal judges of sweeping injunctions against workers in labor disputes. ${ }^{12}$ The cumulative impact of these decisions upon the public mind was great and lasting. Thereafter few writers overlooked the political power of the Court, or depicted the Justices as ethereal beings with little interest in the workaday world. Twentieth-century authors have rather emphasized the all-too-human motives and stratagems at work in judicial deliberations, finding excitement and intrigue where the Victorians sensed only gentle intellectual discourse.

This shift toward a more sensational treatment of Court proceedings coincided with, and was doubtless influenced by, some major changes in the publishing field. America's first mass circulation magazines and newspapers emerged in the 1890 s, bringing with them a personalized and colorful brand of journalism that Theodore Roosevelt once labeled "muckraking." Cheap, well illustrated, and gossipy, these publications catered to a vast audience of middle-class and working-class readers, whose interests had been ignored by the gentlemanly periodicals of the nineteenth century. The spectacular success of the new media insured that information of a sort about the Supreme Court would filter down even to semiliterate immigrants, through the use of cartoons and simplistic editorial comment. Readers who would never have plowed through the staid columns of the Nation could nevertheless relish Mr. Dooley's apt comment on the Insular Cases (1901): “[N]o matther whether th' constitution follows th' flag or not, th' supreme coort follows th' iliction returns." $1: 3$

The image of a politicized Court, which dominated the fiction of the Progressive era, found its earliest expression in several Utopian novels that were written in direct response to the conservative decisions of 1895 . Each of these thinly disguised tracts followed a similar plot line, and each called for a "peaceful" or "legal" revolution to restore political power to the people. Since, according to the authors, every branch of the government was controlled by corporate interests, fundamental change could only be brought about through the assembling of a "people's convention" to rewrite the Constitution. The new charter invariably borrowed planks from the Populist program and granted to the federal government regulatory power that had recently been denied by the Supreme Court. Its ratification by a nationwide popular referendum signaled the beginning of a golden age of political justice.

Henry O. Morris, whose Waiting for the Signal (1897) went through several printings, dramatized the people's case against the Court more effectively than other Utopian novelists. Morris did not balk at introducing living persons into his story and rather appropriately permitted Eugene Debs to deliver the principal attack on the high bench:

The money power now dominates every department of justice, even to the Supreme 
bench [Debs asserts]. It is not possible for a poor man to get in to the Supreme Court. It is omnipotent and answerable to nobody. A short time ago Congress passed a law taxing the rich of the country, and this court adjudged it unconstitutional. If this law had been a tax on the poor, it would have been all right. Under the laws of the land the rich are always right, the poor are always wrong. ${ }^{1.4}$

Through its subservience to corporate wealth the Court unwittingly starts a revolution. Under pressure from the "multimillionaires," the Justices declare that all labor organizations are proscribed by the Sherman Act. Thereupon the workers go underground, form secret revolutionary lodges, ally with other discontented social groups, and prepare to take over the government. On May 1 successful, and generally bloodless, coups occur across the country. Only in New York City-the cesspool of corporate America, in Populist thinking-does widespread violence and destruction result, as the plutocrats hire an army of criminals to resist the people's forces. Once order is restored, the commanding general calls for the election of delegates to a constitutional convention. This body, which meets in Chicago on July 4, drafts a people's constitution that guarantees employment to every person, revives the income tax, toughens the antitrust laws, and nationalizes the railroads and telegraph companies.

Morris provided his readers with the complete text of the new Constitution, whose stipulations concerning the judiciary are instructive. Except for limiting judicial tenure to a single term of eight years, the framers left the basic powers of the Supreme Court intact. They did, however, add several sections that were aimed at curbing some recently perceived abuses of the judicial function. Article III, section 4, declared:

Injunction[s] shall not be granted for light or trivial causes. No court shall have power to issue an injunction restraining a citizen or citizens from leaving the employment of any individual or corporation or from assembling on the public highways.

And section 5 drastically curtailed the power of federal judges to punish for contempt. ${ }^{15}$

More radical assaults upon judicial independence appeared in the model constitution proposed by Frederick Upham Adams in his novel President John Smith (1897). Adams advocated a majoritarian democratic state in which the popular will could not be overridden by any governmental agency. Accordingly, his constitution denied the Supreme Court jurisdiction over all "laws passed by the people of the United States." Since every major piece of legislation had to be referred to the people for approval or rejection, Adams's system left the Justices with relatively little to do. They were required to furnish Congress with advisory opinions on the constitutionality of pending measures, but their advice might be ignored. If, despite these restrictions, they ever proved troublesome, they might be removed from office by a majority vote of the people.

While the Utopian novelists fitted the Court into cosmic visions, other writers of the early twentieth century probed more deeply into judicial values by concentrating on particular decisions. In The Radical (1907), a 
Socialist novel, Isaac Kahn Friedman showed how one Justice had been inexorably conditioned by his socioeconomic background to vote against the constitutionality of a child labor law. "And of those others [on the Court]," Friedman added, "shall it not be said that they were human, therefore fallible too, swayed by the prejudgments and the class consciousness of those to whom they owe birth, education and power, as unable to represent abstract justice as democracy to phrase it!" 16

Liberal novelists, although less deterministic, were equally outraged at the Court's penchant for upholding property rights at the expense of social welfare. They suggested, however, that the conditions of professional training might be primarily responsible for judicial callousness. Robert Herrick's A Life for a Life (1910) portrayed the Justices as ancient logicmachines, programmed to respond only to the legal formulae of a preindustrial age. When a government lawyer in an important antitrust case urges public policy considerations upon the Court, one Justice inquires irritably: "Is it law or equity you are discussing?"17 The defendant corporation wins the case, because its counsel avoids all mention of justice or morality, and argues instead from "irreproachable logic." Herrick's scene imaginatively captures the formalism of American jurisprudence at the turn of the century, when law was widely regarded as an objective science whose progress depended upon a strict adherence to established precedents.

But reformers may also wield precedents effectively, as demonstrated by David Graham Phillips in The Fashionable Adventures of Joshua Craig (1909). Josh Craig, the hero of this novel of manners, is a Lincolnian type, a crude but crafty Westerner who comes to Washington to serve as Deputy Attorney General. Handed an almost hopeless case to argue on his first appearance before the Court, Craig confounds all expectations by winning a victory for the government. The key to his success, Phillips makes clear, lay in his style of advocacy, not in the fairmindedness of the Justices:

Never was there a better court manner; the Justices, who had been anticipating an opportunity to demonstrate, at his expense, the exceeding dignity of the Supreme Court, could only admire and approve. As for his speech, it was a straightway argument; not a superfluous or a sophomoric word, not an attempt at rhetoric.... There is the logic that is potent but answerable; there is the logic that is unanswerable, that gives no opportunity to any sane mind, however prejudiced by association with dispensers of luxurious hospitality, of vintage wines and dollar cigars, however enamored of fog-fighting and hair-splitting, to refuse the unqualified assent of conviction absolute. That was the kind of argument Joseph Craig made. And the faces of the opposing lawyers, the questions the Justices asked him plainly showed that he had won. ${ }^{\text {H }}$

Despite their occasional insights into judicial behavior, the novelists and playwrights of the early twentieth century did not succeed in creating a believable picture of the Court at work. They found it difficult to translate their political and economic concerns, such as trust-busting, into dramatic courtroom material; they knew little about appellate procedure, and nothing of the Court's internal administration; and they were singularly 
inept at drawing flesh-and-blood judicial characters. The Justices of Phillips and Herrick are as abstract and stereotyped as those of any antebellum writer: they continue to be aged, passionless creatures whose sole function is to protect from democratic contamination a body of obsolete legal precepts.

Nonfiction writers offered the public a more impressive revisionist view of the Court during these same years. Charles Warren's The Supreme Court in United States History (1922) and Gustavus Myers' History of the Supreme Court of the United States (1912) broke important new ground in their treatment of the high bench and humanized the work of the Justices far better than any contemporary fiction. Warren explored in rich detail the political dimensions of decision-making, including the public's response to major Court pronouncements. "The reaction of the people to judicially declared law has been an especially important factor in the development of the country," he reminded his readers; "for while the Judges' decision makes law, it is often the people's view of the decision which makes history." 19 Warren's sympathetic, but not uncritical, appraisal of the Court's past record relied heavily upon newspaper, periodical and manuscript sources that provided future commentators with a fund of colorful anecdote.

Myers' work, on the other hand, was a vigorous Socialist critique that combed the public records for evidence of the Justices' corporate connections and financial dealings. This information Myers used to support his thesis that the Court had always represented the interests of a dominant capitalist class, whose actions it legitimized through its decisions. In analyzing the Court as a capitalist institution, however, Myers was careful not to impute any personal wrongdoing to the Justices. "The influences so consistently operating upon the minds and acts of the incumbents were not venal, but class, influences," he noted, "and were all the more effective for the very reason that the Justices in question were not open to pecuniarily dishonest practices.".21" Muckraking novelists might have profited greatly from a reading of this book, but it produced no significant fictional reverberations.

Indeed, there were no real advances in the imaginative portrayal of the Justices until the 1960 s, although the Court impressed itself upon the public consciousness as never before during the constititutional crisis of the early New Deal. Franklin Roosevelt's court-packing effort, and the judicial decisions that preceded it, stirred up much partisan journalism, of which the best remembered example is probably Drew Pearson and Robert $\mathrm{S}$. Allen's caustic study, The Nine Old Men (1936). But no novelist took up the Court fight for another quarter century. Nor did it inspire any stage productions, with the single exception of Kaufman and Hart's musical comedy, I'd Rather Be Right (1937).

In this zany production Franklin Roosevelt (played by George M. Cohan, in his last starring role) wanders around Central Park trying to think up ways to balance the budget so that his two young friends, Phil and Peggy, can get married. Every time he comes up with a new idea for a law, however, the Supreme Court Justices-all looking like clones of Charles 
Evans Hughes-pop up from behind rocks and bushes, to warn: "Oh, no! No, you don't!" Matters reach a climax of sorts as Roosevelt speculates about running for a third term, only to be told by the Chief Justice that that, too, would be unconstitutional. Angrily Roosevelt retorts:

Don't give me that. The Constitution doesn't say a word about it. I know my Constitution.

THE CHIEF JUSTICE

Oh, you do, do you? Well, Mr. President, the Court has just been in session, and we have just declared the Constitution unconstitutional... How do you like that?

ROOSFVEIT

'That's fine. That's all we needed.... Tell me something-is there anything left in this country that still is constitutional?

Yes. The Supreme Court...."1

THE CHIFF JUSTICF

The Justices, it turns out, are mad at Roosevelt mainly because he called them "old fogies." To prove that they are not, they give a shrill whistle, summoning nine shapely chorus girls who join them in a strenuous song-and-dance number titled "Having a Iittle Constitutional Fun." After this, they all disappear again into the bushes. Roosevelt, looking after them, muses: "You know, if I'd suggested putting six new girls on the Bench, I'll bet they'd have said, 'All right'."':2

Kaufman and Hart's conception of the Justices as nine foxy grandpas may not mark a step forward in literary interpretation, but it does offer a welcome respite from the conventional image of judicial solemnity. Other works of the 1930s attest to the heightened sense of drama that surrounded important Court decisions in a time of national emergency. Particularly striking in this regard is Arthur Arent's play Polver (19:37), one of the "Living Newspaper" productions commissioned by the Federal Theatre. Designed for popular audiences of limited means, the "Living Newspapers" dramatized contemporary social problems by combining imaginary characters and incidents with recreations of real-life events, as reported in the daily press.

Arent argued the case for public ownership and distribution of electrical power, and brought the Court into his script as a kind of deus ex machina. Using a stylized representation of the high bench surmounted by nine illuminated facial masks, he quoted directly from the majority and minority opinions in Ashwander $v$. TVA (1936), a decision that upheld the constitutionality of TVA legislation within narrowly defined limits. ${ }^{2: 3} \Lambda \mathbf{s}$ the decision is announced, a character shouts: "TVA has won!" Immediately, according to the stage directions,

$\Lambda$ crowd of people comes on from all entrances as red, blue, yellow and amber sidelights light up the entire stage. An impromptu parade is started. They throw streamers and confetti and $[a \mid$ general carnival spirit prevails." 
But the Voice of the Living Newspaper interrupts, to report a later development: A new test case has been brought by the private power companies, and they have won in the federal district court. The play thus ends on a cliffhanging note, as the narrator underscores the importance of this new challenge to federal power:

LOUDSPEAKER: Again the question marches toward ultimate decision by the Supreme Court... (Rear traveler curtains open and lights come up on Supreme Court)... of the United States. The fundamental constitutionality of TVA will be decided. Upon it will rest the social and economic welfare of the people of the Tennessee Valley... (Red, yellow, blue and amber side-lights come on to half, covering the entire group standing down stage in front of platform)... and the character of future legislation for Boulder I)am and other projects through which the people seek to control their water power, to save their soil, and to obtain cheap energy. (All people on stage take one step fortuard.)

ENSFMBLE: What will the Supreme Court do?

(A huge question mark is projected on to the scrim as the

Curtain falls.

('The question mark remains on house curtain until house lights are brought up.):i:

One can scarcely imagine a more effective way of demonstrating the power of the Court to affect the lives of average Americans.

In the 1940 s and 1950s several new trends, both jurisprudential and literary, coalesced to make the Court a more attractive and accessible subject for creative writers. First in importance was a major change in the kinds of cases that came before the Court. After 1937 the Justices accepted the legitimacy of federal and state economic regulation, and turned their attention increasingly to civil rights issues. Through the due process clause of the Fourteenth Amendment they gradually applied the guarantees of the Bill of Rights for the first time to the states. This trend, which was accelerated during the era of the Warren Court, brought up for decision a whole new range of problems that were at once controversial and inherently dramatic, such as the rights of suspects in state criminal proceedings.

The activism of the Warren Court further inspired a vigorous and well publicized debate over the proper role of the judiciary in modern society. Legal realists had long insisted that judges should be creative policymakers, allowing their sense of fair play and other extraneous factors to guide their decisions. Some members of the Warren Court appeared to be realists, others advocates of judicial self-restraint. Novelists and playwrights recognized the dramatic potential in such conflicting philosophies, and took note as well of the cries for Warren's impeachment that arose periodically from disgruntled segments of the public.

Certain advances in the art of judicial biography also increased the attractiveness of the Court as a literary subject. The spectacular success of Catherine Drinker Bowen's A Yankee from Olympus (1944)-which was in turn a best-selling book, a play, a movie and a television dramaemphasized that there was a definite market for gossipy stories about the private life of a colorful judicial personality. Mrs. Bowen's sentimental, and somewhat cloying, portrait of Oliver Wendell Holmes, Jr. harked back in 
some ways to the tear-jerkers of the nineteenth century; but none could deny that the public loved it.

Quite different in design and execution was Alpheus Thomas Mason's Harlan Fiske Stone: Pillar of the Law (1956), a massive award-winning study that illuminated the inner workings of the Court as no previous book had done. Mason made extensive use of Stone's personal papers, which included draft opinions circulated among the Justices for their individual comments. This evidence exposed the bickering and bargaining that went on among the Justices in important cases, and some reviewers charged that Mason had violated the privacy of the Court. Perhaps he had, in some respects; but his book nevertheless provided invaluable insights into the Court's deliberations, and served as a model for later judicial biographies. Within its line of descent I would include Woodward and Armstrong's recent bestseller, The Brethren." ${ }^{\prime \prime}$ Although The Brethren is often tasteless and sensational where Mason's book was restrained and scholarly, the two works use comparable source materials to explore the private relationships among the Justices.

By the $1960 \mathrm{~s}$, as popular nonfiction studies of the Court multiplied, writers began to produce the first full-length treatments of the high bench in American literature. Six works of fiction have been published since 1963 that examine at length the internal and external pressures operating upon the Court. Four of these are novels: Andrew Tully's Supreme Court (1963), William Woolfolk's Opinion of the Court (1966), Henry Denker's A Place for the Mighty (1973), and Walter F. Murphy's The Vicar of Christ (1979). Two plays complete the list: Jay Broad's A Conflict of Interest (1972) and Jerome Lawrence and Robert E. Lee's First Monday in October (1978).

Collectively, these works tend to follow a common format: A new Justice is appointed to the Court. He (or she) meets the brethren, each of whom expresses a clearly articulated juristic philosophy and displays some distinguishing personal eccentricity. The physical and intellectual traits of living Justices are carefully scrambled, so that recognizable liberals come out sounding like conservatives, and vice-versa. The new appointee finds himself immersed at once in a series of dramatic cases. These generally involve recent civil rights issues that have been widely discussed in the media. After hearing oral argument the Justices deliberate gravely, even portentously, with one another. They are well aware of the historic dimensions of their work. As one character puts it, "One could look at a finished opinion and know that it would shape the future course of the law and perhaps even western civilization." 27 Often tempers flare; brawls break out in the robing room, and acrimonious debate resounds at the conference table. But at some point institutional loyalties prevail over personal differences, as the Justices join in a common effort to save the Court from some external danger, usually provided by a new court-packing plan or a threatened impeachment.

To balance these professional tensions, most authors add a generous share of painful domestic problems. The central judicial character in many cases turns out to be a man of early middle age, whose romantic involvements threaten to impair the moral influence of the Court. A few 
examples: Shall debonair bachelor Francis Dalton, 43, the youngest Justice on the Court, go through with his plans to marry a beautiful actress, knowing that her scandal-ridden past will shock the public and trouble some of the brethren? (Supreme Court). Or, shall Associate Justice Paul Lowe, 46, a rugged Nebraskan, divorce his wife of twenty-five years, whom he has never really loved, to marry an exciting newswoman who is secretly dying of leukemia? (Opinion of the Court). Such situations suggest the major weakness of all these books: Despite their well researched backgrounds and sensible discussions of current constitutional questions they never rise above the level of soap operas. They are essentially novels of ideas, in which cardboard characters are manipulated according to the dictates of a predetermined plot line. Even so, in their breadth of coverage and credible supporting detail, these works represent a tremendous advance over all previous fictional interpretations of the Court.

In surveying the cultural scene today, one is most forcibly impressed by the continued outpouring of Court-related materials of all kinds. The public, it appears, has an insatiable desire to know more about the institution and its personnel. Even the juvenile market bears witness to this fact. There are presently nine books on the Court written for students in elementary and secondary schools. They are surprisingly effective in describing how the Court functions and in dramatizing major decisions. But at least one author sensed that his young readers would soon be demanding more information than he had given them. "The Supreme Court's opinions fill more than 350 volumes," he cautioned. "Don't try to read them all." $2 \times$

Some may argue that much of this publicity is counterproductive and only lowers the Court in public esteem. But on that point the views of the Justices themselves are instructive. Although many have discussed the question over the years, no one has better expressed the prevailing opinion than Associate Justice David J. Brewer, who observed back in 1898:

It is a mistake to suppose that the Supreme Court is either honored or helped by being spoken of as beyond criticism. On the contrary, the life and character of its justices should be the object of constant watchfulness by all, and its judgments subject to the freest criticism. The time is past in the history of the world when any living man or body of men can be set on a pedestal and decorated with a halo. True, many criticisms may be, like their authors, devoid of good taste, but better all sorts of criticism than no criticism at all."?

\section{Notes}

'Joseph Blotner,'The Modern American Poltical Novel, 1900-1960 (Austin: Univ. of Texas Press, 1966); Gordon Milne, The American Political Novel (Norman: Univ. of Oklahoma Press, 1966).

'For examples of trial scenes in early plays, see James Nelson Barker, Superstition; or, The Fanatic Father (1824), reprinted in Arthur H. Quinn, ed., Representative American Plays (New York: Century Co., 1917); and Joseph Stevens Jones, The People's Lawyer (1839), reprinted in Montrose J. Moses, ed., Representative Plays by American Dramatists, vol. 2(New York: I)utton, 1925).

"Quoted in Robert Kenneth Faulkner, The Jurisprudence of John Marshall (Princeton: Princeton Univ. Press, 1968), 67. 
'[George Watterston], The L.... Family at Washington (Washington: Davis \& Force, 1822), -113-114.

IIbid., 115.

'Jay Broad, A Conflict of Interest(New York: S. French, 1974), 38. The play opened at Washington's Arena Stage in January 1972.

${ }^{7}$ George Van Santvoord, Sketches of the Lives and Judicial Services of the Chief-Justices of the Supreme Court of the United States (New York: Scribner, 1854), 482.

“On Marshall's textbook reputation, see Ruth Miller Elson, Guardians of Tradition: American Schoolbooks of the Nineteenth Century (Lincoln: Univ. of Nebraska Press, 1964), 210.

'Martin R. Delany, Blake; or, The Huts of America, ed. Floyd J. Miller (Boston: Beacon Press, 1970), 61 .

'"Ibid., 263.

"Madeleine Vinton Dahlgren, A Washington Winter (Boston: Osgood \& Co., 1883); Thomas Fleming, Around the Capital With Uncle Hank (New York: Nutshell Pub. Co., 1902).

1:The decisions referred to are United States v. E.C. Knight \& Co., 156 U.S. 1 (1895); Pollock v. Farmers' Loan \& Trust Co., 158 U.S. 601 (1895); and In re Debs 158 U.S. 564 (1895).

1.'Edward J. Bander, ed., Mr. Dooley on the Choice of Law (Charlottesville: Michie Co., 1963), 52.

'Henry O. Morris, Waiting for the Signal (Chicago: Schulte Publishing Co., 1897), 228.

1.ibid., 350.

"i'I.K. Friedman, The Radical (New York: Appleton, 1907), 337.

'Robert Herrick, A Life for a Life (New York: Macmillan, 1910), 222.

'David Graham Phillips, The Fashionable Adventures of Joshua Craig (New York: Grosset \& Dunlap, 1909), 75.

1"Charles Warren, The Supreme Court in United States History, 2 vols. (rev. ed., Boston: Little, Brown, 1926), I, 3.

"Gustavus Myers, History of the Supreme Court of the United States (reprint ed., Chicago: Charles H. Kerr \& Co., 1918), 8. 119 .

$\because$ George S. Kaufman and Moss Hart, I'd Rather Be Right (New York: Random House, 1937),

:-Ibid., 6:3.

$2: 297$ U.S. 288 (19:36).

"Arthur Arent, Power, in Federal Theatre Plays (New York: Random House, 1938), 88.

Ibid., 91. For an excellent scholarly appraisal of the work of the Federal Theatre, see Jane De Hart Mathews, The Federal Theatre, 1935-1939: Plays, Relief, and Politics (Princeton: Princeton Univ. Press, 1967).

يliBob Woodward and Scott Armstrong, The Brethren: Inside the Supreme Court (New York: Simon \& Schuster, 1979).

:Walter F. Murphy, The Vicar of Christ (New York: Macmillan, 1979), 138.

¿'Harold Coy, The First Book of the Supreme Court (New York: Franklin Watts, 1958), 28. The other juvenile titles currently (1980) in print are Andrew David, Famous Supreme Court Trials (gr. 5 up) (Minneapolis:. Lerner Publications, 1979); David F. Forte, The Supreme Court (gr. 7 up) (New York: Franklin Watts, 1979); Barbara Habenstreit, Changing America and the Supreme Court (gr. 7 up) (rev. ed., New York: Julian Messner, 1974); Gerald W. Johnson, The Supreme (ourt (gr. 5-9) (New York: Morrow \& Co., 1962); Anthony Lewis, The Supreme Court and How It Works (gr. 6.10) (New York: Random House, 1966); Helen S. Peterson, The Supreme Court in Ainerica's Story (gr. 3-6) (Champaign: Garrard Publishing Co., 1976); Kenneth Richards, The Story of the Supreme Court (gr. 4-8) (Chicago: Childrens Press, 1970); and Peter Sgroi, Blue Jeans and Black Robes: Teenagers and the Supreme Court (gr. 7 up) (New York: Julian Messner, 1979).

${ }^{3 ! !}$ Quoted in Wesley McCune, The Nine Young Men (New York: Harper Bros., 1947), vii.

Maxwell Bloomfield is Professor of History at The Catholic University of America, Washington, D.C. His publications include American Lawyers in a Changing Society, 1776-1876.

'Ihis essay was commissioned by the Supreme Court Historical Society and delivered as the Society's Annual Lecture in June 1980. 
Copyright of Journal of American Culture (01911813) is the property of Popular Press and its content may not be copied or emailed to multiple sites or posted to a listserv without the copyright holder's express written permission. However, users may print, download, or email articles for individual use. 